[The following Correspondence was submitted at the Second Meeting (12th December 1902).]

\title{
Mathematical Correspondence
}

Robert Simbon, Matthew Stewart, James Stirling.

[The correspondence which is here printed was bought by me on the $28^{\text {th }}$ of March 1887 at the sale of the Gibson-Craig collection of Scottish MSS.

Simson's letters, which are beautifully written, seem all to have passed through the post, but Stewart's letters are, I conjecture, merely the drafts of what he proposed to send. The handwriting of the latter, though legible, is not elegant, and there are frequent erasures. I have scrupulously respected, in all the letters, the spelling, the punctuation (or want of it), the use or disuse of capitals, and I have made no attempt to improve the style.

A few of Simson's letters are given in the "Account of the Life and Writings of Robert Simson" by the Rev. William Trail (1812), and a few more in some articles, "Geometry and Geometers," by Thowas Stephens Davies in the Philosophical Mragazine, $3^{\text {rd }}$ series, vol. 33, pp. 201-206, 513-524 (1848).

In one of these articles [Philosophical Magazine, $3^{\text {rd }}$ series, vol. 37, p. 198 (1850)] Davies states that he applied to an eminent archæologist to ascertain what had become of Matthew Stewart's MSS. "In a short time he sent me the copy of a letter from the proper custodian of the papers, decisive on this head. They are all destroyed-deliberately burnt; and not only his, but likewise all the MS. of his son Dugald Stewart."

The following remarks and dates regarding the authors of the correspondence may save the reader the trouble of consulting a cyclopædia or dictionary of biography; if they do not, so much the better.

Robert Simson was born in Ayrshire on 14 $14^{\text {th }}$ October 1687. In 1711 he was appointed professor of mathematics in Glasgow University, where he had studied, and one of the first subjects 
which attracted his attention was Euclid's Porisms. Simson was the first of the modern mathematicians who discovered, from the description left by Pappus, what the nature of the ancient porisms was. He published a paper on this subject in the Philosophical Transactions of the Royal Society of London in 1723, but his treatise De Porismatibus did not appear till after his death. His Sectiones Conicae was issued in 1735 ; his restoration of Apollonius's Loci Plani was finished about 1738 but not published till 1749. His Elements of Euclid both in Latin and English appeared in 1756, and in 1762 he added Euclid's book of Data. In 1761 he resigned his professorship, and on $1^{\text {st }}$ October 1768 he died. In 1776 his Opera Quaedam Reliqua was edited by James Clow, to whom all Simson's manuscripts were bequeathed, and printed at the expense of Philip, Earl Stanhope. This work contains a restoration of Apollonius's treatise De Sectione Determinata with the addition of two more books, the Porismatum Liber, a book on Logarithms, and a fragment on the Limits of Quantities and Ratios.

Matthew Stewart was born at Rothesay in the island of Bute in 1717. He entered the University of Glasgow in 1734, and in 1741 went to the University of Edinburgh to prepare for entering the Church. He attended the lectures of Maclaurin during session $1742-3$, on $6^{\text {th }}$ May 1744 was licensed by the Presbytery of Dunoon, and on $9^{\text {th }}$ May 1745 was presented by the Duke of Argyll to the living of Roseneath. For the chair rendered vacant by the death of Maclaurin in June 1746, Stewart became a candidate, and issued his Some General Theorems of considerable use in the higher parts of mathematics (the preface is dated October 1, 1746). Stewart obtained the chair in September 1747, and discharged the duties of it till $17 i 2$, when his health gave way. His distinguished son Dugald undertook to lecture in his stead, and in 1775 was appointed jointprofessor. Stewart died on $23^{\text {rd }}$ January 1785 .

In 1756 Stewart gave, in the second volume of the Essays of the Philosophical Society of Edinburgh, a solution of Kepler's problem; in 1761 he published I'racts, Physical and Mathematical; and in 1763 Propositiones Geometricae more Veterum denonstratae. An obituary notice of him by Professor John Playfair will be found in the $1^{\text {st }}$ volume of the Transactions of the Royal Society of Edinburgh. 
James Stirling was born at Garden in Stirlingshire in 1692 . He was educated at Glasgow University, and matriculated at Oxford on $18^{\text {th }}$ January $1710=11$. In 1715 he was expelled from Oxford for corresponding with noted Jacobites, and went to Venice. While he was there he made the acquaintance of Niclaus Bernoulli, who was professor of mathematics at Padua. He returned to London about 1725, and in the following year was elected a Fellow of the Royal Society. In 1735 he was appointed manager to the Scots Mining Company at Leadhills. But for his Jacobite principles he might have been Maclaurin's successor. He died in Edinburgh on $5^{\text {th }}$ December 1770 . He published in 1717 a commentary on Newton's lines of the third order, Lineae tertii ordinis Neutonianae, sive illustratio tractatus $D$. Neutoni de enumeratione linearum tertii ordinis, and added two new kinds to the seventy-two which Newton had remarked among curves of the third order. At p. 32 of this work occurs the theorem which usually goes by the name of Maclaurin's theorem. In $173 \mathrm{~J}$ he published his Methodus differentialis seu de summatione et interpolatione serierum infinitarum.

J. S. MaCKax]

To

Mr Robert Statson

Professor of Mathematics

in the University of Glasgow

ED*. Jan. 3, 1741

Sir

I expected to have had the Pleasure of seeing you at Glasgow on my way here, but as you was otherwise taken up so that I could not see you then, I hope Sir, you will excuse my giving you the trouble of this Letter. In October last I found out a Theorem which I thought might be of some service towards finding the Quadrature of the Hyperbola and very soon afterwards $I$ found a Construction of that Problem. I delayd doing any further till I should have occasion to see you at Glasgow and know from you what Gregory in his Vera Circuli et Hyperbolæ Quadratura had done towards the solving of this Problem, I not having access to see that Book in Bute, but being disapointed of seeing you at Glasgow I expected when I came here to have access to see that Book, and 
accordingly I enquird for it at the Publick Library but was told that Mr M'Laurin had it from the Library, so that I do not expect to see that Book $I$ not having occasion to be the least acquainted with Mr M'Laurin. I have therefore Sir, usd the Freedom with you, to send you the Theorem and the Construction and humbly Intreat the Favour of you to let ne know your opinion of them and what Gregory has done, if you will be so good as to write me within a post or two,

You will very much oblidge Sir,

Your most Humble and

Obedient Servant

Mat'tn Stewart.

P.S. Please direct for me at

Mr Will!.. Sand's

Bookseller in Parliament Closs

To

Mr Matthew Stewart

at Mr William Sand's Bookseller

in the Parliament. Closs

Edinburgh.

Glasgow 16th $\operatorname{Jan}^{r} 1741$.

\section{$D^{2}$ Matphew}

I am ashamed when $I$ look upon the date of yours of $\operatorname{Jan}^{\mathrm{ry}} 3^{\mathrm{d}}$ that $I$ have been so long in answering it, and am sorry I cannot this post send you a full account of what $\mathrm{Mr} \mathrm{Ja}$ : Gregory has done in the problem of squaring the Hyperbola, for this is the $4^{\text {th }}$ letter I have wrote this night, and have not time before the post goes of to send you it, but if you cannot find the book by the directions I now give you let me know by monday's post, and I shall write a letter that will procure you a sight of it. The treatise de Vera Quadratura Circuli et hyperbola is reprinted in the $2^{\mathrm{d}}$ Vol. of Hugenii opera Varia. and Guido Grando's Theorematum Hugenianorum Demonstratio is in the $1^{\text {st }} \mathrm{Vol}$. of Hugenii opera reliqua i.e. in the $3^{\mathrm{d}}$ volume of the four which contain all his works. this last I mean Grando's book I believe contains a good deal more of what you want to see than Gregory's. Huygens works being but 
lately printed I cannot but think you will meet with them in some Booksellers shop, if not I desire you may go to $\mathrm{M}^{x}$ Tho. Ruddiman keeper of the Advocates Library and give my service to him, and tell him I desire the favour of his letting you see both these books. if you get them not thus, I shall upon your letting me know it, send you in a letter that will obtain a sight of them. fail not to let me hear from you, I have no time to write any thing about your Propositions, but that the mutual relation of the Hyperbola and Logarithmick Curve you will find fully in Huygens theorems above mentioned.

I am

Dear Matthew

Yours affectionately

RoB: Simson.

To

Mr Matthew Stewart

at Mr William Sands Bookseller

in the Parliament Closs

Edinburgh.

\section{Dear Matthew}

Glasgow 25.. Febr. 1741.

I Received your letter of the $19^{\text {th }}$ with the Answer to the Problem enclosed. I had seen the Problem about 2 weeks ago in the Magazine, and answered it upon the reading of it, without putting pen to paper, which was owing to my having long before this had the Loci, to which this is easily reduced. Your Lemma I demonstrated, but have not considered how it is to be applied, And indeed I could not so much as get time to write you this by monday's post, as I had fully designed.

You desire me to revise the Answer and return it with any alterations or Additions, but considering that there are only the bare Propositions : I see not what alterations you can mean except in the Stile; with respect to which I would not have you use the word reason but ratio. And the way of speaking major dato quam in ratione, is by no means intelligibly translated greater by a given space (or square) and in reason. for example your $5^{\text {th }}$ Prop. which stands thus "If it were proposed that the Excess of the sum of the 
"Squares of the lines drawn from the first above the sum of the

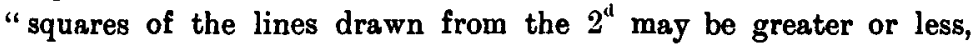
"than the sum of the squares of the lines drawn from the $3^{\mathrm{d}}$ by a "given square and in reason" would be plainer in English thus viz. If it were proposed that the Excess of the sum of the squares of the lines drawn from the first above the sum of the squares of the lines from the $2^{a}$; diminished or encreased by a given square may have a given ratio to the sum of the squares of the lines drawn from the $3^{4}$.

Two of the following Propp. seem to differ only in this that what is called the first in one is the $2^{\mathrm{d}}$ in the other and vice versa dc. I desire you will be so free with me as to let me know whether any person besides yourself is concerned in the Answer, or even in the Question; for if you be only concerned in them; I can give you some hints that may be worth your while. but if another person is really the proposer and that you are quite ignorant who he is, I would, if in your case, let him give in his own answer.

I have enclosed your paper, and shall be glad to hear from you with the first conveniency. I am in hast, wishing you all success in your inquiries

\section{Dear Matthew}

Your affectionate most humble

Servant

RoB: Simsor.

Let me know what occasioned the bringing Polygons into the Problem since it would be more general, to have made use of points. and $\mathrm{I}$ suppose you know one of the Propositions in your answer is a Locus of Appollonius which has been shown several ways; That Locus of Apollonius I have long ago found out his own solution of, which I have shown to severals. be so good as to take no notice of the contents of this to any body. which I have observed with respect to your Answer most strictly.

If you will send your solution to the case of 3 points and 2 which is one of the simplest; I shall give my Judgment impartially with respect to the comparison of yours and my own.

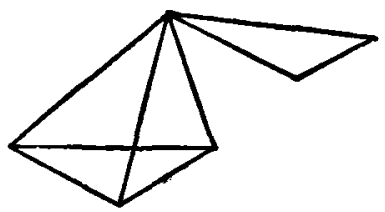

I should be glad to see you soon here, but whenever you come be sure to call at me. adieu. 
To

Mr Robert Simson Professor

of Mathematics in the University

of

Glasgow.

ED. Feb. 28. 1741.

Sir

I received yours of the $25^{\text {th }}$ and am very much oblidgd to you for letting me know any alterations you thought proper to be made in the Answer I sent you last week.

There was one part of your Letter, Sir, which I do not fully understand namely, "Two of the following Propp: seem to differ only in this, that what is called the first in the one is the $2^{\mathrm{d}}$ in the other and vice versa, I wish you would let me know the particular Propositions, and likewise that one which you say is a locus of Appollonius. As I have never seen any of Appollonius's works I do not know which of them it is.

The method I take to find the Construction of the Problems containd in the Answer, is by reducing them to more simple Problems, which may be done by the Lemma in the Answer, the most of them for example may be reducd to this one.*

"Given two points in a plane from which there are drawn lines " concurring in a point in the same plane that the square of one of " the lines diminishd or encreasd by a given Square may be to the "Square of the other line in a given ratio, requird the locus of the "point where the lines concurr.

I would be glad to know your Construction of this Problem, and likewise your Demonstration of the Lemma, the Demonstration I have, being very tedious. I have sent, as you desird, my Solution to the case of 3 points and 2 , but am very far from thinking that it will be in the least comparable to yours.

You desire me to be so free with you as to let you know if any other Person beside myself be concernd in the Answer or even in the Problem.

I sincerely declare, Sir, that there is no person but myself concernd either in the Answer or in the Problem, for I am not in the least acquainted with any person here that pursues the Study of Mathematics that I know off; nor did I ever exchange Letters with any person concerning that Study but yourself, Sir, And I should

* See Robert Simson's Loci Plani (Glasguae, 1749), p. 227. 
be very glad how often I should have occasion to exchange Letters with you, Sir, as $I$ am very sensible $y^{t}$ you are both willing and capable to give me many usefull hints and Advices concerning that Study.

The occasion of bringing Polygons into the Problem and Answer, was, because I found some difficulty in the expressing of them when I made use of points. As I do not know when I shall go to Bute, I am very sorry that $I$ have no prospect of seeing you soon, tho I am very desirous of having the pleasure of seeing you upon several accounts.

I am Sir Your most

Humble and Obedient

Servant Matrh STRWART

To

Mr Matthew Stewart

at Mr William Sand's

Bookseller in Parliament Closs

Edinburgh

\section{D? Matrhew}

GLasgow $13^{\text {th }}$ March 1741.

I designed to have wrote to you last post but was prevented. I have now come from a Company and sent you the demonstration upon the other side in a great hurry, So Excuse any thing amiss but send me a double of it when you have leasure for I have none i.e. no copy to my self. You see it agrees to both cases. the Demonstr. of the 1 st sent formerly might also have been transferred to 24 case, but I thought you would like this better. Your observation about the sum of the squares of lines drawn to the center is right, that sum being together with the multiple of the square of the semi diameter by the number of points equal to the given space. I cannot add a word more and have disobliged I fear those that I left who have sent for me half an hour ago, so must leave what else I was to say till next letter. Let me know if you easily and generally deduce the propertie of center of gravity by your Method.

I am

Dr Matthew

Yours affectionstely

RoB: Simbor

Let me hear from you

with first conveniency. 
Prop.* Si a vertice $A$ Trianguli $\mathrm{ABC}$ ducatur ad basim recta $A D$, a puncto vero $D$ ducantur $D E, D F$ lateribus $A C, A B$ parallelae, ipsisque in $\mathrm{E}, \mathrm{F}$ occurrentes ; Erust rectangula $\mathrm{BAE}, \mathrm{CAF}$ simul aequalia quadrato ex $\mathrm{AD}$ et $\mathrm{BDC}$ rectangulo. Si vero ducatur $A D$ ad basim productam, reliquis manentibus, erit excessus rectangulorum BAE, CAF aequalis excessui quadrati ex $\mathrm{AD}$ et rectanguli $\mathrm{BDC}$.
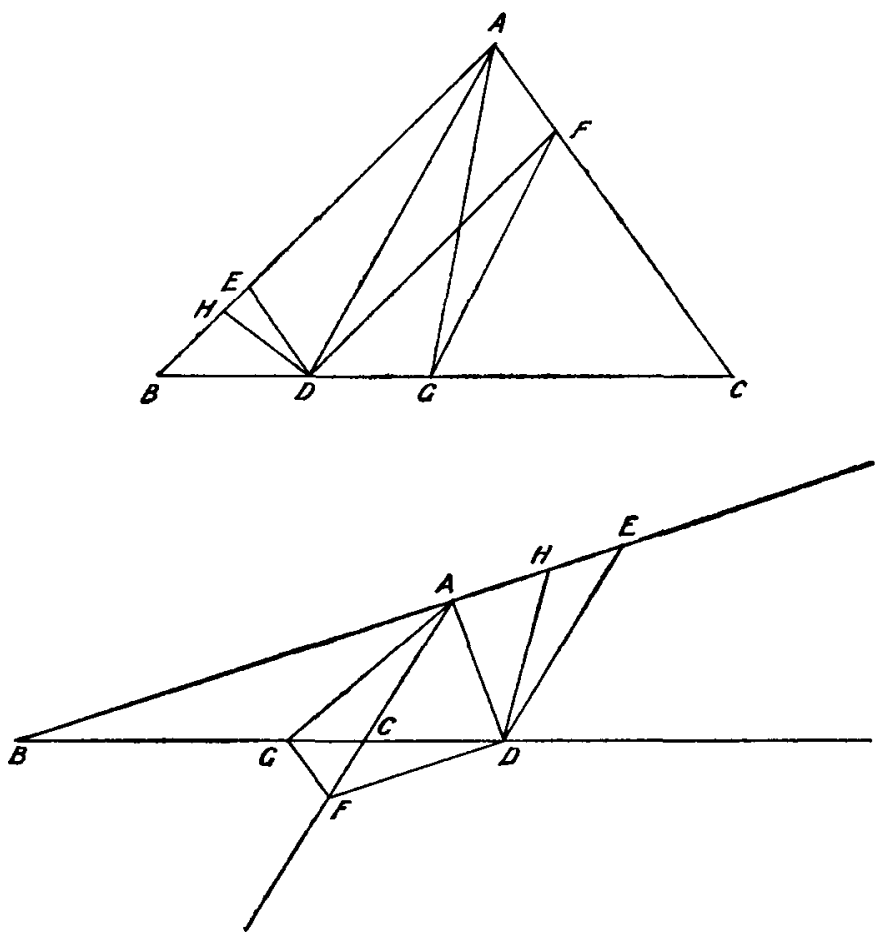

Ad $B C$ ducatur recta $A G$ faciens angulum GAF aequalem ipsi $A B C$ seu FDG; a puncto vero $D$ ducatur ad $B A$ recta $D H$ faciens angulum $\mathrm{ADH}$ aequalem angulo $\mathrm{AED}$, et in triangulis $\mathrm{ADH}, \mathrm{AED}$

* This is the first proposition of Matthew Stewart's Some General Theorems (Edinburgh, 1746). Stewart's demonstration is different from Simson's. 
quae communem habent angulum DAH, erit reliquus angulus AHD aequalis reliquo $\mathrm{ADE}$ hoc est alterno angulo $\mathrm{DAF}$. Quoniam vero aequales sunt anguli GAF, FDG erunt puncta $G, D, A, F$ in circulo ; quare junctâ GF, erit in Fig. 1. erit angulus exterior FGC aequalis interiori et opposito DAF in quadrilatero DAFG, hoc est angulo AHD ; et propterea est angulus DGF aequalis ipsi DHB. In Fig. vero $2^{\text {th }}$ est angulus FGD, aequalis ipsi FAD, in eodem sc: segmento circuli, hoc est angulo AHD. Aequales igitur sunt anguli FGD, AHD in utraque figura, et in triangulis DGF, BHD aequales etiam, propter parallelas, sunt anguli FDG, HBD quare [4.6.] est $B D$ ad $B H$, ut $D F$ ad $D G$; et rectangulum BDG aequale erit rectangulo contento ipsis $\mathrm{BH}, \mathrm{DF}$, hoc est contento $\mathrm{BH}, \mathrm{AE}$. Et quoniam ex constructione angulus $\mathrm{ABC}$ aequalis est ipsi $\mathrm{GAC}$, et, in triangulis BDE, ACG propter parallelas est angulus BDE aequalis angulo GCA ; erit [4.6.] $\mathrm{BD}$ ad $\mathrm{DE}$, ut $\mathrm{AC}$ ad $\mathrm{CG}$; quare rectangulum contentum $\mathrm{BD}, \mathrm{GC}$ aequale est contento $\mathrm{AC}, \mathrm{DE}$ hoc est rectangulo CAF. Et ostensum fuit rectangulum rectangulum $B D G$ aequale contento $B H, E A$; Ergo in figura $I^{m a}$ rectangulum $B D G$ una cum contento $B D, G C$, hoc est [1.2.] rectangulum $B D C$ aequale est contento BH, EA ura cum ipso CAF rectangulo. In triangulis autem $A H D, A D E$ quoniam aequales sunt anguli ADH, DEA et communis DAH, erit rectangulum HAE aequale quadrato ex $\mathrm{AD}$ in utraque fig: Ergo, additis aequalibus, erit rectangulum contentum $\mathrm{BH}, \mathrm{EA}$, una cum ipsis CAF, HAE hoc est erunt rectangula BAE, CAF simul aequalia rectangulo BDC una cum quadrato ex $A D$ in fig. sc: $I^{2}$. In fig. vero $2^{\text {das }}$ est [1.2] rectang. BAE una cum ipso $\mathrm{HAE}$ aequale contento ipsis $\mathrm{BH}, \mathrm{AE}$ hoc est (ut ostensum fuit) rectangulo BDG, hoc est ipsi BDC et contento BD, GC sinul; hoc est ipsis BDC, CAF. Ergo $\mathrm{BAE}, \mathrm{HAE}$ rectangula hoc est $\mathrm{BAE}$ rectangulum et quadratum ex AD aequale est ipsis BDC, CAF. et propterea excessus ipsorum BAE, CAF aequalis est excessui rectanguli BDC et quadrati ex AD.

Q.E.D. 
To Mr Robert Simson Professor

of Mathematics in the University of

Glasgow.

ED: Mar 28.1741.

SIR

I received yours together with your Construction of the locus of Appollonius, which gave me a great deal of Satisfaction, as you was pleasd to let me know that you design soon to publish your treatise de locis planis, and that the Theorems I sent you might, if it was agreeable to me, appear to better advantage there than in the Magazine, You need not doubt, Sir, but that it will be very agreeable to me, as I am persuaded they can appear no where to so good advantage. I shall send you them and likewise the method $\mathrm{I}$ take to demonstrate them, as soon as I can, but you will find it absolutely necessary to put them in another form before they can deserve a place among any of yours. I will very cheerfully give you all the Assistance $I$ can in Copying your treatise and drawing the Figures.

I find the Printers of the Magazine have got sent them an Answer to the Problem with some very severe reflections upon the Antients, particularly Appollonius, the Answerer observes that the analysis they had is but very lame and obscure in comparison of the modern Algebraic method, and affirms that they did not even fully understand any kind of analysis they had. I do not know if this Answer will be publishd, but if you please, Sir, I can privately procure you a Copy of it.

I am told that there is one Jack a Teacher of Mathematics in this Town about, to publish a Translation of your Conics. I would be glad to know if he has your Concurrence.

I am Sir your most Humble and Obedient Serv ${ }^{t}$

MatTh Stewart.

Sir.

I have sent you inclosd the analysis of the first of the loci mentiond in my last, upon which I found the second entirely 
depended, the case when the two right lines given by position are not parallel, I found might be very easily deduc'd from the $44^{\text {th }}$ and $45^{\text {th }}$ of 5 . Conies, but when the right lines given by position are parallel, does not appear to me to be so easily deduc'd. I have likewise sent you the analysis of this locus.

If from two given points $A, B$, there be drawn $A C, B C$ to a point $C$ and let $A C, B C$ cut $D F, E G$ two right lines given by position in $\mathrm{D}, \mathrm{E}$, such that the segment of the right line DF intercepted between $\mathrm{D}$ and the given point $\mathrm{F}$ may be to the segment of the line $\mathbf{E G}$ intercepted between $\mathbf{E}$ and the given point $\mathrm{G}$ in a given ratio, or that the rectangle of these segments may be given, requird the

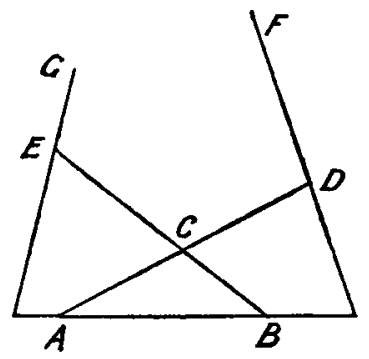
locus of the point $\mathrm{C}$. By the method I took to analyse these loci I reducd them to the locus, of the Antients to four streight lines. After the same manner, when the rectangle ACB is to the rectangle $D C E$ in a given ratio or the rectangle $A C E$ to the rectangle $B C D$ in a given ratio, $I$ found the locus of the point $C$ to be a Conic Section. I have sent you inclosd likewise the Construction I have of the Problem in the Magazine, [about a dozen of lines have been crossed out here] but will reserve the Construction of the other Loci I wrote you some time ago till I see you. I wish A. B were desird to send the Construction of the two Loci he mentions in the Conclusion of his paper, which he promises to do when desird, for it would appear I think, from the way he expresses them, that he mistakes them quite.

I would be very glad to have the pleasure of a Letter from you, with your Conveniency and to have your remarks upon the two inclosd papers.

Mr Jack I am told, Sir, still continues his design, he gives out that he at first thought it would be agreeable to you, but that he now finds the Contrary, he proposes to make considerable Alterations.

I am Sir Your most humble and obedient Serv ${ }^{\mathrm{t}}$ MaTrH

STEWART

ED $^{\Re}$ July $20-1741$. 
To

Mr Matthew Stewakt

at Mr-William Sands's bookseller

in the Parliament Closs

Edinburgh.

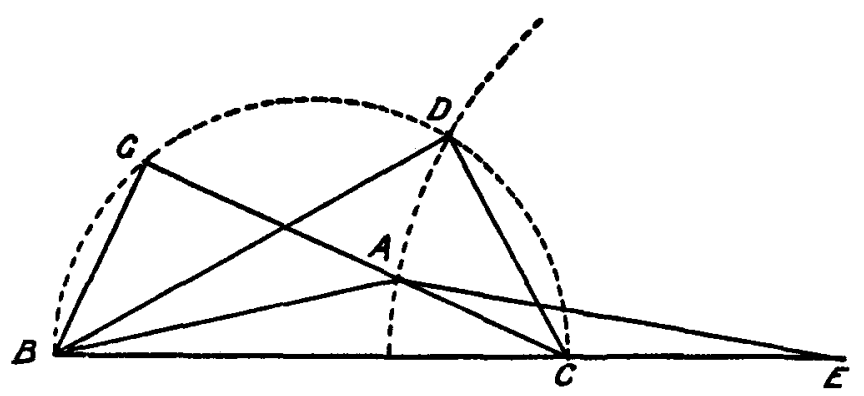

Sir

GlasGow 29:. Vor: 1742.

I got your letter of the $20^{\text {th }}$ Current, for which I am obliged to you, and am well pleased with your account of the reason of not writing sooner, and that $\mathrm{Mr}$ M'Laurin has received you kindly. I got no leasure to consider the Porism which you sent till saturday last. It is elegant and wants not difficulty as you observed. Pray let me have your construction of it by next letter. I here send you mine.

Iet $A B C$ be a given triangle (in position) \&c. as in your letter. Upon BC the base make the Triangle BDC having a right angle at $D$, and its sides $B D, D C$ in the same proportion with $B A, A C$ (which may be done by making the angle $\mathrm{CAE}$ equal to $\mathrm{ABC}$ and describing from center $E$ thro $A$ a Circle meeting one described on $B C$ as a diameter in $D$ and joining $B D, D C) D$ shall be the point sought, and, the perpendicular $\mathrm{BG}$ being drawn upon $\mathrm{CA}$, the ratio sought shall be that of the square of $B G$ to the square of $B D$, viz: this is the ratio the sum of the squares of the perpendiculars has to the square of the line drawn from the point in the base to the point $D . \quad I$ am in much haste

$\mathrm{D}^{\mathrm{r}}$ Matthew

Yours affectionately

Rob : Srmson. 
SIR

Ed. Dec. 2. 1742.

I had yours of Nov? 29th for which I heartily thank you, I have sent, as you desird my construction of the Porism which differs very little from yours. I have likewise sent you another Porism, which to me appears to be more elegant than the first the construction of which I am not quite Master of at present but shall in my next, if desird, send you it. In my last I told you that I delayed writing to you till I would know if $\mathrm{Mr}$ M.Laurin was to have a fourth class. for he seem'd to be uncertain when I spoke with him, the reason why I thought he was then uncertain was that when I offered him money, he refusd it and told me, he would talk of that again with me after he had taken up his fourth class, accordingly I went to him, since I wrote you last, and offerd him money again, but was extremely surprised to tind he would by no means take it, he told me I was very welcome to attend any of his classes I thought proper, but that he would take no money from me, I thought myself bound to write you this, as I am persuaded $\mathbf{M r}$ M'Laurin's extraordinary civility to me must be entirely owing to you. I would be glad to hear from you soon. I am

Sir, your most Humble \& obedient

Servant M.ATth STewaRT.

In the base $B C$ take the point $\mathrm{D}$ such that $\mathrm{BD}$ may be to $\mathrm{DC}$ as the square of $\mathrm{AB}$ to the square of $\mathrm{AC}$ at $\mathrm{D}$ erect $\mathrm{DE}$ perpendicular to $\mathrm{BC}$ and let the square of $\mathrm{DE}$ be equal to the rectangle $\mathrm{BDC}$, $\mathbf{E}$ is the point given.
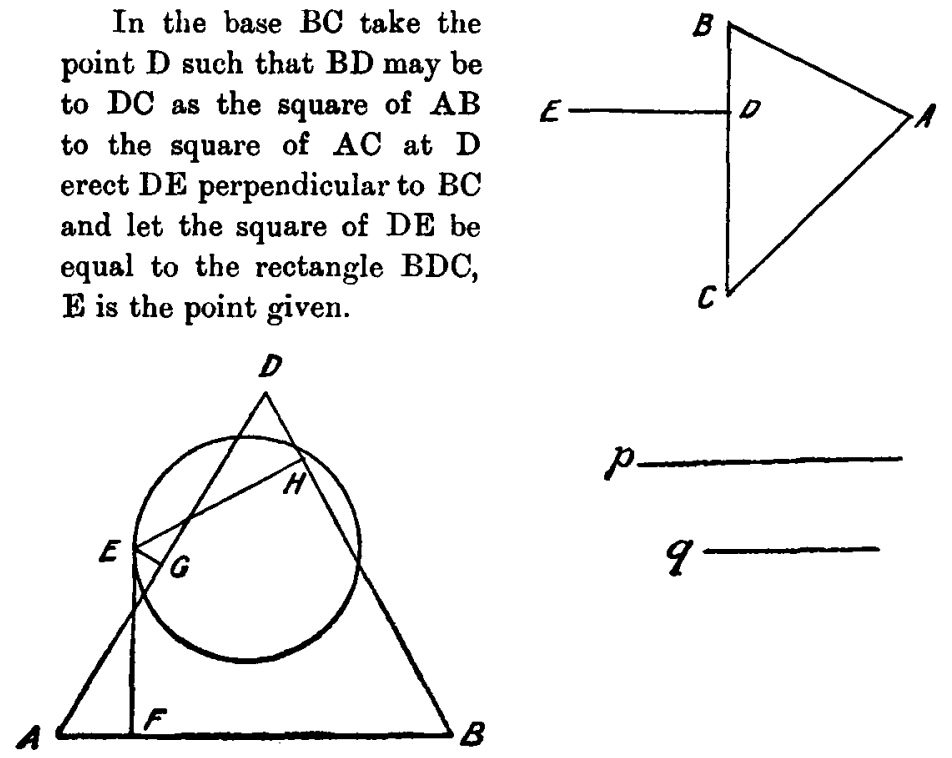
Porism. Let there be a circle and a right line $A B$ both given by position, and let $p, q$ be two given magnitudes. two right lines $A D, B D$ are given by position, such that if from any point $\mathbf{E}$ in the circumference of the circle there be drawn perpendiculars to $\mathrm{AB}, \mathrm{AD}, \mathrm{BD}$ meeting $\mathrm{AB}, \mathrm{AD}, \mathrm{BD}$ in F, G, $H$ the square of EF together with the space to which the sum of the squares of EG, EH has the same ratio that $p$ has to $q$ will be given

but $p$ must be greater than the half of $q$.

To

Mr Matraew Strewart

at Mr William Sands's bookseller

in the Parliament Closs

Edinburgh.

\section{Dr Matthew}

GLasgow $27^{\text {th }}$ Dec. 1742

P.S. Let me have any Mathematical news.

You may think $I$ have too long delayed answering yours of the 2 d of this month, but it is very seldom I can have the quiet that is proper for considering such questions as the last you favoured me with, and I liked not to write to you before I had considered it. It is a very elegant porism and wants not difficulty, when you send any such again you may send at the same time your solution of them which will save me time. I renew the desire I made to you when last here that you would not communicate these things till I see you at least; In the meantime I wish you would as your leasure can permit find out as many as may be of them, and be sure to write down both Analysis and composition, because when I publish an account of the Porisms I shall be glad to have your store to encrease mine which shall every one of them be particulary acknowledged in the book. Let me have your Construction by next post, and explain what you mean by saying you were not quite master of it when you wrote ; be pleased to let me know if you have made it known to any. I doubt not the Construction $I$ have given you upon the other side will please you. I have wrote the whole of this in company rather than delay it till another Post and am 
ashamed to keep the gentleman that is with me any longer in waiting. So can only add that the Porism may be made more generall if proposed thus.

Having given in position a streight line and a circle and two angles $A$ and $B$. There shall be given in position two streight lines such that if from any point in the circumference there be drawn to those lines, two others which make with each of the former the angle $A$, and a third line to the line given in position making with it the angle $B$, the sum of the squares of all three shall be given.

\section{I am}

Yours affectionately RoB: Sinson.

P. Data positione recta AB, et. circulo, cujus centrum $\mathrm{C}$ et semidiameter positione dato, datâque ratione $\mathrm{FG}$ ad GH ; Dabuntur positione duae rectae $L M, L N$ ad quas, ut et ad rectam $A B$ ductis a quovis in circumferentia puncto $Q$ perpendicularibus QR, QS, QT: Quadratum ex ea QR quae ad AB ducta est, una cum spatio quod ad summam quadratorum ex reliquis rationem habet eandem quam $\mathrm{FG}$ ad $\mathrm{GH}$, aequale erit spatio dato.

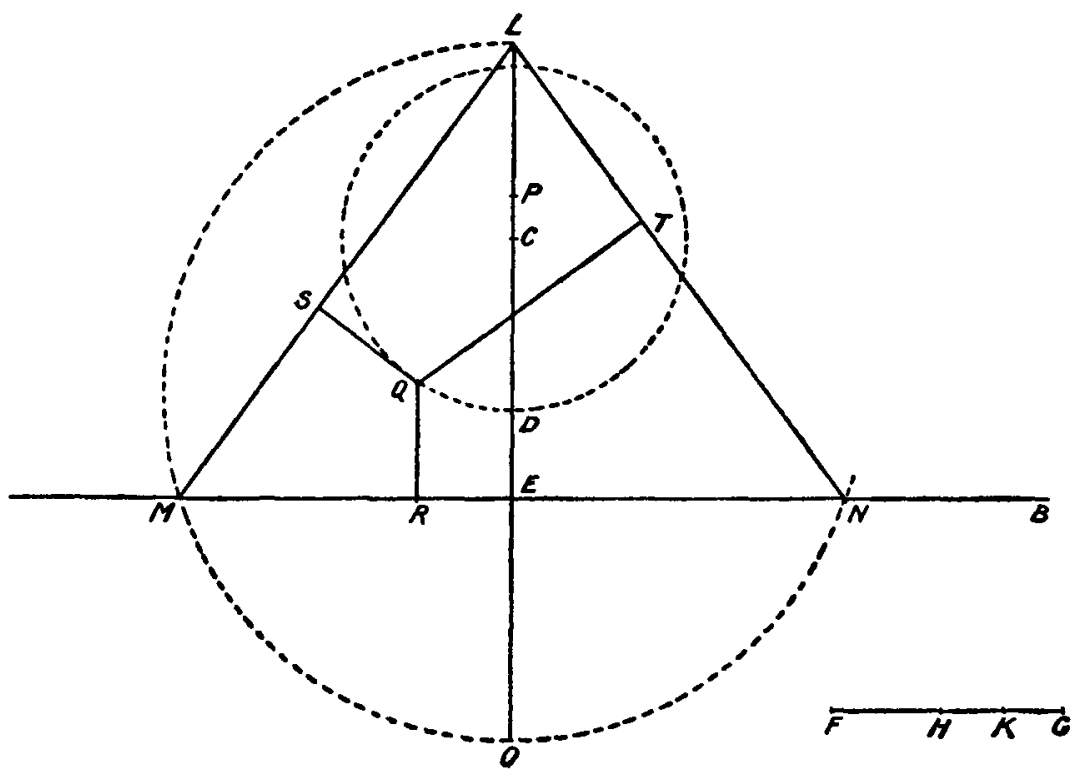


Const. Ducatur ad AB perpendicularis $\mathrm{CE}$ (quae occurrat circulo in D) et bifariam sectâ $\mathrm{HG}$ in $\mathrm{K}$, fiat ut $\mathrm{FK}$ ad HG, ita EC ad quartam CL quae ponatur in EC producta, in qua, ad contrarias partes, sumatur EO ipsi EC aequalis, et super diametrum LO descriptus circulus occurrat rectae $A B$ in $M, N$ punctis.

Junctae LM, LN erunt rectae quaesitae. Et in EC producta sumptâ CP tertia proportionali ipsis LC, CD ; erit rectangulum LEP spatium quaesitum.

Excuse any errors may be upon the other side, for I have not time to examine it. also keep this leaf for $I$ have no double of it, or of the Scheme.

ED. Dec. 30. 1742.

SiR.

Yours of the 27th instant came safe to hand which gave me a good deal of satisfaction, as I had long'd very much for an answer from you. When I mention'd in my last the Porism whose construction you was pleas'd to favour me with $I$ had not the least intention of mentioning it to you by way of question. all I proposd to myself was to have your opinion of it, my not sending the construction of it at that time was purely owing to my not being then quite Master of it as you may easily perceive by my not mentiong a limitation which is absolutely necessary namely that the magnitude $p$ must be greater than the half of $q$, this limitation I did not observe till after I had seal'd your Letter and had not then time to alter it, as my construction is almost the same with yours save only that yours exceeds mine somewhat in simplicity $I$ think it needless to send you mine. You renew the desire you made to me when I saw you last that $I$ would not communicate anything relating to Porisms to any here, this, Sir have religiously observ'd and will observe. You desire $\mathrm{y}^{t} \mathrm{I}$ should investigate as many Porisms as $I$ can and write down their Analysis and composition, and are pleased to signify to me your inclination to take notice of them in a way, which I own Sir I never expected, as I never had such an high opinion of myself as to think I was capable of investigating any thing that would deserve a place among yours, however, I shall endeavour to investigate as many as I can, and am hopefull to be in condition to investigate sixteen if not twenty that appear to me 
intirely new, most of which $I$ expect will exceed the one sent you last in difficulty and elegance, what makes me expect to be in condition to investigate so many is this, I have for some time past been thinking on several Propositions that to me appear to be intirely new, and was resolvd as soon as possible to put them in the best order I could and to publish some small thing that might be a specimen both to my Friends and others of my having dealt somewhat in this Study, I [did not incline to write you-scored out] was not resolv'd to Publish any of my Propositions in the form of Porisms, tho that was the form I thought several of them ought to appear in, but as you was pleasd to let me know that you had some thoughts of publishing something on this subject soon I was resolv'd as much as possible to avoid any thing that would seem to have the least tendency to this. I did not incline to write you [anything-scored out] concerning this my design till $I$ had put my Propositions into order, and was resolv'd then if it would be acceptable to you that you would do me the honour to revise them, but upon receipt of your last I have laid this design intirely aside, but will endeavour as soon as possible to put them in the best order I can, that you may [pick - scared out] choose out such as you think proper for your design, the end I mentioned to you I propos'd to my self by publishing some small think, [sic] will be accomplishd by this in a manner beyond my expectation, only I must own Sir I. would be extremely satisfay'd, were it agreeable and convenient to you that your Book were publishd as soon as possible not only with regard to myself, but to every one that has a regard for ancient Geometry a Book of this kind is very much wanted, and I am persuaded as you have long had the Publishing of this Book in your view, you can in a very little time prepare it for the Press. the design of the inclosd paper is this, Mr Mr'Laurin seem'd to insinuate to me that his civility to me which $\mathrm{I}$ mentioned to you in my last was owing to his having had a character of me, this occasiond my giving him this Paper, since I wrote you last, which he read over, and told me at the same time that he thought it would be worth my while to explain these things more fully. I did not give him in the least any hint of the method I had for explaining these things. I have not spoke with him since concerning this paper, I hope you will not think by my stowing him this paper that I have acted contrary to the promise made to you, but 
if you think proper I shall for the future observe a profound silence with regard to any things of this Nature. the first thing mentiond in the paper I told you of a twelvemonth ago.

I conclude this long and tedious Letter with earnestly entreating the favour of a Letter from by next post if possible which will be very acceptable to

\section{Sir Your}

P.S. Sir you'll please take care of the enclosd paper as I have no copy of my self and may perhaps incline to see it afterwards.

Mr Matthew Stewart

To

at Mr. William Sands's bookseller

in the parliament closs

\section{Edinburgh}

\section{$D^{R}$ Matrhew}

GLasGow $3^{\imath} \cdot \operatorname{Jan}^{r} 1743$.

I received your agreeable letter in due time, but by reason of a faculty meeting on fridays night could not write a return. the hurry on new years day and another faculty this night, the papers for which $I$ have but just now prepared, prevents me from writing now at the length I designed. I am glad you bave so many Propositions which may be put into the form of Porisms, and wish to know in what manner you designed to have published those you speak of, because if you think it would be too long to defer till I could publish the account $I$ am to give of the Porisms when yours might be published in the form of Porisms, (such I mean as properly could be brought into that form) they might be printed as an Appendix to the Loci plani in the form you had designed to print them in yourself, at the same time you might add the Locus you printed in the Magazine and such of those others connected with it us you thought fit. I want only the figures and to transcribe a few pages of the Loci plani to have them ready for the press, And design, if by any means I can prevail with you, to have you with me here as soon as you leave Edinburgh, till the book be printed. you need not be solicitous about expenses in staying here, which I shall make very easie to you. As to the keeping private what 
relates to the porisms I an obliged to your prudence which I hope you will continue for reasons will satisfie you fully at meeting. In the meantime you will think it reasonable, how much soever I encline to communicate any small things $I$ have that may be of any use to the publick, that I should be the first publisher myself; and this has made ne keep the porisms to myself, Except the few hints Mr Ja: Moor, John Williamson and yourself got from me. Let me know whether of the 2 ways above you like best, or if this $3^{d}$ will not be as good as either, viz: To print at the end of the Loci plani the paper you designed to print by itself, And to gather all the porisms you can find, \& I shall publish these in the form of Porisms with those few of Euclid I have been able to discover, Mr. Fermat's and my own, in the account $I$ am to give of the Porisms which will be some small time after the Loci plani are published, I mean within a year or thereabouts. I am obliged to break of and have just time to add that I am exceedingly pleased with the propositions you enclosed some of which $I$ saw in the reading how they might be done. they and the propositions on which they depend deserve well to be published both as they are elegant new and usefull. I am

\section{Dr. Matthew}

Your very affectionate

humble servant

RoB: Simson.

I had designed to mention the limitation you speak of in my last but forgot. the ratio viz: must be greater than that of 1 to 2 . You need not be afraid of my losing the paper or iny you have sent or shall send.

Sir.

I send you this in answer to yours of the $3^{4}$ instant which came to me in due time, I am at a loss how to express my thankfulness to you for the kind offer you make me of printing the Papper I design'd to publish, at the end of your Loci plani by way of Appendix. I enclin'd Sir to publish some small thing as soon as possible, for a reason mentiond in a former Letter, and as you are pleasd to acquaint ine that you want only the Figures and to transcribe a few pages of the Loci plani to have them ready for the press, and have made me the kind offer above mention'd I frankly 
own Sir your kind offer is very agreeable to me. as to the manner I design'd to publish I was not fully determin'd till $I$ would have finishd all I design'd to and was resolv'd to be directed by you then to publish in the manner you would think properest. I would be glad to know from you Sir, in what Volume you design to publish your Loci plani and if you design to have it printed here, if you be under no engagement to any printers here $I$ would fain hope the two printers with whem my Brother in Law is in Company would serve you as well and as reasonably as any here, they were both with Mr Ruddiman when your Conics were a printing and had then in a manner the whole charge of the printing. Mr Jack inclind to have employd them to print his Book, but as I happend to be in Town then and had got notice of his design, I told my Brother that I knew Mr Jack's design was intirely disagreeable to you, which oceasiond their deciining to be concernd in such an injurious design. You may perhaps Sir incline to have it printed at Glasgow I would be loth to insinuate any thing against the Glasgow printing as I very well know the Gentlemen you will in that event employ, they may indeed have as good types as the types here but it is plain that the Glasgow printers are not so much master of the press casting off as those here, and that a Book suffers as much by bad casting off at the press as by bad types, and I should be sorry that your Book should meet with any injustice this way as it is very probable that it will reach several places abroad [all the corners of Europe-scored out]. I hope Sir you will excuse me in the freedom I have used, I would not have wrote you this Sir were I not persuaded my Letter will fall into no hands but yours. You are pleas'd to write me, Sir, that you design'd if by any means you can prevail with me to have me at Glasgow with you till your Book be printed. you may assure yourself Sir there will be no occasion for Arguments to persuade me to undertake what is so agreeable to ne as I can propose to myself no higher satisfaction than to have the pleasure of your Company for some time, and were I entirely at my own disposal you might command me when you will, but Sir I have reason to expect my friends incline I should be at home this Summer, for reasons I will acquaint you off at meeting, but as I encline very much to your proposal, and were it equally convenient for you that I should come to Glasgow in March or the beginning of April, I should be extremely satisfy'd, I enclin'd 
indeed to attend $\mathrm{Mr} \mathbf{M}$ 'Laurins Lesson till the end but Sir I choose rather to loose his Lessons than be depriv'd of the pleasure I propose to myself by being at Glasgow with you. the reason why I propose to cone to Glasgow so soon is that I expect my Father will agree sooner to this proposal of mine than to others, but I am even afraid he may even oppose this proposal of mine and can think of no better way to procure his consent than by your writting to him. I am persuaded a Letter from you will go as great a way to prevail with him as any thing can do. I would be glad to know if this be agreeable to you. I was designd to have wrote him this night, but shall delay till I have a return from you, which Sir I hope will be by this post if possible.

I am Sir Your most Humble and Obedient Serv ${ }^{t}$

$\mathrm{ED}^{\mathrm{n}} \operatorname{Jan} .6 .1743$.

Matth Stewart

To

Mr Matthew Stewate

at Mr William Sands's Book-

-seller in the Parliament Closs

Edinburgh.

\section{$\mathrm{D}^{\mathrm{R}}$ Matthew}

GLASGOW $7^{\text {th }} \operatorname{Jan}^{r}$. 1743.

Your letter was most acceptable to me. I am as far from thinking ill of the friendly advice you give in relation to the printing of the Loci Plani, that I thank you kindly for having any of my concerns so much at heart. I design the book should be in Quarto tho' it should be never so thin, because I reckon that size most convenient especially in a book where there are Copperplates. As to the printing of it, were it to be at Edinburgh, the civility and kindness which the gentlemen who print for your Brother have shown me in the affair you mention would, as well as the regard you may be sure $I$ have for any of your friends, induce me to employ them rather than others at Edinburgh. And tho' I have made no express promise to $\mathrm{Mr}$ Foulis here, yet having given him ground to expect the employment, I cannot handsomely without 
just reasons give the printing to another, the rather that $I$ know it is agreeable to my good friend $\mathrm{Mr}$ Hutcheson and that $\mathrm{Mr}$ Foulis and his Brother Mr Andrew have for a long time done every thing in their power to oblige me. As to the Casting off at the press, I know what you say is very true; that the workmen here have not been so much masters of it as at Edinburgh but $I$ am told they have of late got some good pressmen here. I wish however you would desire the printers you mention to look into $\mathrm{Mr}$ Hutchesons book just now published, and get their opinion as to the print of it, for I think it looks pretty well and mine being to be in $4^{\text {to }} \mathrm{I}$ think might still look better, but if they think otherways let me know, because I design the book should be both exactly and neatly printed.

I forsaw the difficulty you tell me about your staying here any time; and in hurry when I wrote last forgot to offer you my service to write to your father about it, which I looked upon as the best method to procure the favour of your being allowed to stay here. I am glad you have the same thought. Pray let me know when it will be most proper, now, or some time after this to write to him, which I shall do in the most effectual manner I can. Let me also have his direction and how a letter may be safely sent to Bute, for there is nothing I long more for than to have you some time here.

There is one of the Loci plani of Apollonius viz: (the last of the $1^{\text {to }}$ book as enumerated in Pappus) Si a quodam puncto ad positione datas duas parallelas ducantur rectae in datis angulis ita ut summa vel differentia specierum ex ipsis ductis aequalis fuerit dato spatio punctum illud continget rectam positione datam.* there is no difficulty when only two parallels are given, but when 3 or moe the determination of the Locus grows more operose as well as the Analysis, but the Determination chiefly. I have a particular solution for the case of 3 lines, and a general one for any number, but I thought them so long, that I resolved only to give the case of 2 parallels; if you find a little leasure any time I will be obliged to you if you can find a tolerably short and plain solution which I would insert in the book, for tho' in Dr Halleys translation of Pappus preface printed before his Edition of Apollonius de Sectione rationis there is ad positione datas duas parallelas, yet the number

* This is quoted from Halley's Apollonius de Sectione Rationis (Oxonii, 1706), p. xxxviii. 
of parallels is not mentioned in the Greek, but give yourself no trouble about it except it be for your diversion till you come West.

I am

Dear Matthew

Yours affectionately

ROB: SImBon.

No body shall know any thing of what you write about the printing. Nor do I show your letters to any whosoever. I forgot to tell you that if it could be as convenient for you May would be more convenient for me than April in regard I will be then quit of my classes at least about the middle of it.

SIR, You'll no doubt be somewhat surprised that I have not wrote you before now in answer to yours of the $7^{\text {th }}$ which came to me in due time. I was resolvd to have wrote you by last post but was disapointed for want of time, as I have been for the most part confined to my room since I was favoured with yours, having been somewhat indisposed. I have had no opportunity of desiring the printers to look into Mr Hutchesons Book and give their opinion as to the print of it, but as you seem to be pretty well pleased with the print of and are in a manner engag'd as to the printing of yours already I think it will be quite needless to propose this to them, the rather that I am apt to suspect they will be somewhat shy in an affair of this nature but if you think otherways I shall propose it to them: I am glad to find that you incline to write to my Father yourself to procure his consent to my being some time at Glasgow when I leave this, I am hopefull your Letter will prevail with him, you write me $y^{t}$ if it would be as convenient for me, May would be more convenient for you, in regard you would be then quite of your classes, the reason why I proposd March or April was that either of these months was more convenient for me than may, but that $I$ had reason to suspect my Father inclines $I$ should bo at home as soon as possible, when you write him, Sir, you may propose my coming in May, and if he oppose this which I am hopefull he will not, I will afterwards propose to him my coming in March or April if you incline, I wish you would write him concerning 
this, as soon as you conveniently can, his name is Dugald you may direct for him Minister of the Gospel at Rothesay, Bute, Mr Rankin Tobacconist in the Briggate is a very proper hand to convey your Letter to him I had almost forgot to write you that I had occasion to considder a Little the Proposition you mention in your last, when I was considdering the first Prop mentioned in the paper, I sent you some time ago, but will endeavour to considder it more fully before I see you, I was resolvd to considder the Proposition mention in that paper more fully in what I design'd should be publish'd, but you'll perhaps not think it so proper that any thing that relates to the Loci Solidi, should go along the Loci plani, and therefore if you you incline I shall drop this part of it, the rather that I am afraid it would swell my paper till a greater length than perhaps is convenient, I would be satisfyd to have your opinion concerning this,

ED? Jan. 13. 1743.

To

Mr Matthew Stewart

at $\mathrm{Mr}$ William Sands's bookseller

in the Parliament Closs

Edinburgh

\section{Matthew}

Glasgow 28 Jan? 1743.

I got your letter of the $13^{\text {th }}$ current in due time and was sorry for the indisposition that confined you to your room and hope it is removed long before this. I believe I have reason both from my own experience, and from your great inclination to study, perhaps too uninterruptedly, to caution you to take care of your health by using proper recreation, such as walking abroad in the fields \&c. which will enable you to return to your studies with fresh vigour. Continued studie especially in difficult things without diversion now and then cannot but be very prejudicial to health. when I received yours and some time after I was likewise indisposed and obliged to keep my room for some days but was not quite well during a forth. night and this is the reason that frst kept me from answering yours 
the day I received it, and to tell the truth when I grew better I forgot to write till now.

I agree with you that it is quite needless to ask the printers any question about $\mathrm{Mr} \mathrm{H}-$ n's book. I shall god willing write to your father very soon in the terms we have agreed on. I mean to let you stay here some time, and shall let you know his answer as soon as I get it. I am glad you had occasion to consider the Locus I wrote about, as to the Locus Solidus you mention I think you judge very right that it comes not in so naturally with the Loci plani, and therefor since you have enough beside it will be best to omit it. I have part of the Loci Solidi wrote, and if yours (the Locus Solidus) or any other you have or may find out happen not to be printed till I have mine ready we shall joyn them together. I have had a touch of the cholick which keeps me within today but is not so severe as to hinder me to write this. pray let me know by first post how you have been since you wrote, and give me any of your literary news. I am

Dear Matthew

Your affectionate humble Servant

RoB: Srmbox.

Sir. I was favoured with yours of $\operatorname{Jan} 28$, and would have wrote you a return by that post had I not been interrupted when about to write. I was sorry to find that you had been for some time indisposd and am hopefu] that you are now perfectly recovered. I have been pretty well since I wrote you last I was resolvd to have wrote you a long letter now, and to have your opinion concerning the method $I$ ought to follow in the analysing of Problems, but as I have not time just now to propose my difficultys, I shall write you again within a post or two. I have nothing further to write you now, but that I long much to hear how you are. I am

$$
\begin{gathered}
\text { Sir, } \quad \text { Yours \&c } \\
\text { Matte Stewart. }
\end{gathered}
$$

[This letter is not dated, but from Simson's reply it will be seen that it was either sent or received on 1st February, 1743.] 
To

Mr Matthew Stewart

to the care of Mr William Sund's

Bookseller in the Parliament closs

Edinburgh.

Glasgow 24. March 1743

\section{Dear Matthew}

Because in your last letter of the $1^{\text {st }}$ of February, you wrote that in a post or two you would propose your difficulties about the method you were to follow in the Analysis of Problems, I did not send you an answer, expecting your letter very soon. but now I am afraid either that your health has not been as I wish or that some unforseen accident has hindered you. Let me know then by first post how all goes with you. And particularly take care and be cautious how you engage to agree to a proposal I believe has either already been or will soon be made to you about going to $\mathbf{P}$ __ gh, * tho' the post is honourable enough, yet I would not wish any $I$ have so great regard for as $I$ have for you to be sudden in accepting of it. Mr Jo: Williamson, and I believe Mr James Muir too had that proposakmade to them, but neither would accept; nor do I believe your father would agree to it. I have written to him and soon expect an answer which $I$ shall let you know of as soon as I get it. pray let me hear from you

I am

Dear Matthew

\section{Yours Affectionately \\ Rob: Simson}

Sir

ED. Mar 29. 1743.

I am very much asham'd, when I reflect that in my last to you, I promis'd to write you in a post or two, and have your direction how I was to proceed in the Analysing of Problems, and that I should have delay'd writing you so long. The true reason is this, when I wrote you last, I had then in view two Problems which I had been for some time before that thinking on, and when I attempted to solve them, I found them vastly difficult, and was very much at a stand what method to take to analyse them, which

* Petersburgh. 
occasion'd my writting you in that manner, but upon second thoughts, I thought it better to delay considdering of them till I should be at Glasgow where I would have better access of letting you know my difficultys than by writting, especially as I foresaw they would cost me more time than I could well spare, for $\mathrm{Mr} M \cdot \mathrm{L}-\mathrm{n}$ drives very furiously thro his Fluxions and $I$ encline to keep as close pace to him as possible. I am very much oblidg'd to you for the insinuation you gave me in your concerning the proposal of going to $\mathbf{P}-$ gh. On this day three weeks ago, I was sent for by $M r M \cdot I--n$, who upon my coming to him, show'd me a Letter he had got by that Day's post from London, concerning that affair, and when I had read it over, He made me an offer of that business in a very pressing manner. I was very much surpris'd at the offer, and propos'd to him some difficulties I had with respect to myself against accepting of that offer, He told me he would be against my accepting of it unless he got the terms settled in the best manner possible, and ample security that $I$ should be at Liberty to come home when I encline'd after I had been three years there. I must own, as the affair was represented to me by him, I would have made no difficulty of accepting it, and told him so, that if my friends would agree to it, (which I was afraid they would not,) I would accept of it. He desir'd me to write as soon as possible to my Father concerning this affair, which I did in a very pressing manner, and soon had his return diswading me from it in the strongest terms imaginable. I told $\mathrm{Mr} M \cdot \mathrm{L}$ - $\mathrm{n}$ so, and that as $\mathrm{I}$ found it was so disagreeable to My Father I did not incline to accept of it. He told me he was to make an offer of it to $\mathrm{Mr}$ Williamson or Mr Muir. He told me that he had wrote to his correspondent that he had me in view and that if $\mathrm{my}$ friends would give way to it, I would accept of it, and promisd to let me know when he got a return from his correspondent. This is all I know concerning this affair. I would be glad to know how you came to suspect the offer was either made or soon would be made me, and likewise your difficultys against accepting it. You will no doubt be very much surpris'd that in an affair of this kind I did not write you to have your opinion how I should behave, the truth is, I enclin'd very much to write you, but was diverted from it, for a reason $I$ choose rather to acquaint you off when we meet, than write you. I would have wrote you this by last post in answer to yours but was interrupted when about to write you. I have kept

3 Vol. 21 
this affair as private as possible as $I$ do not encline it should take air by my means. I would be glad to have a return from you as soon as you conveniently can.

This from Sir your most

Humble Servt.

M

To

Mr Matphew Stewart

at Mr William Sands's Bookseller

in the Parliament Closs

Edinburgh.

\section{Dear Matherew}

Grasgow 20". April 1743.

I got your letter of March $29^{\text {th }}$ in due time which I delayed to answer in expectation of getting one from your father which has within this hour come to my hand of the date 29th March in which very civilly he grants my request as you may see by the last sentence of it which I here have copied that you may fully know his mind, It is "As I would cheerfully goe into your desire as far "as is consistent with our affairs and views, so I shall be well pleased "how soon he comes home, That (if possible) matters may be so " concerted, as he may be in condition to return to you, and to his "power serve you for a few weeks, as your letter mentions." So you may take your own tine, as far as is consistent with your fathers desire, of staying at Edinb ${ }^{x}$ : I shall be done with my classes in a few weeks and so in condition to use your assistance after you have seen your friends a few days at Bute.

I am glad you are not going to $\mathrm{P}-\mathrm{gh}$. what relates to my coming to know of that affair and the reasons $I$ have against it I shall defer till meeting. I am just now called upon to go out so wishing you may take sufficient care of your health while $\mathrm{Mr}$ M'Laurin drives on so fast and you consequently in a constant intensness of mind which needs more relaxation than $I$ believe you use, I am

$D^{x}$ Matthew

Your very affectionate humble Servant

RoB: Simson. 
$\mathbf{T}_{0}$

Mr Matrhew Stewakt

To the care of the Reverend Mr Dougald

Stewart Minister at

Rothesily in

Bute.

\section{Dear Matthew}

GLasgow $5^{\text {th }}$ August 1743.

Mr White having with some strangers been at the College yesterday enquired earnestly at me for you, and how he could get a letter conveyed to Bute: I undertook to send it, so he has just now sent it to me. I believe it may come by some of Ascocks servants, John Rankin having told me he was to go for Bute tomorrow. this is all the occasion of my writing. I desire you may let me know how all affairs go with you. Tho Mr Moor has been a long time at the goat milk with Kilmarnocks family, and is still busied about them, he has got time to draw all the schemes of the $1^{\text {st }} 20$ Propositions save 3 , and sayes when he returns, which will be middle of next week he'l soon get the rest done; he went through the town to day with the E. of Kilnm: \&c. and I believe will go to Buchanan with them. I have got all wrote but the $6^{\text {th }}$ of $B .2$, the Cases of which rightly to distinguish, as I told you, was the only difficulty which I have now digested, but not wrote down. after you went off I vexed myself some further about the Proposition with the 8 cases, and have got it done in single lines in any easy way, tho subject to the varieties of comp. $\&$ divid. \&c. I hope to see John Williamson here before he go for England, and would be glad it happened when you were here. I give ny very kind respects to your Father and am ever

Dear Matthew

Yours affectionately

RoB: Simsox

Pray let me know particularly how my Lord and Lady Bute \& all the family are. adieu. 
SIR. I long very much to hear how you are and to know how far the Loci plani are advanc'd in the Printing. I have been so much taken up since $I$ saw you in preparing for our Presbytery $w^{c}$ is to meet very soon, that $I$ have had very little time to employ in Mathematical Enquirys. I have got a very simple Construction of this Problem, a Conic Section being given and two right lines $A B, A C$ being given by position intersecting each other in the point $A$ to draw a right line $B C$ touching the Conic Section in the point $D$ and meeting $y^{e}$ right lines $A B, A C$ in $B, C$ such that $B D$ may be to $C D$ as the square of $A B$ to the square of $A C$. I have not had time yet to write the Construction, however if you are desirous to see it I shall send you it in my next. Upon this problem depends the solution of this other problem a Conic Section being given, and any number of right lines likewise given by position to find a point in the Conic Section such that drawing from that point right lines in given angles to the lines given in position the sum of the squares of the lines drawn, may be a Minimum. I am persuaded such as deal in the Calculus would find insuperable difficulties in the solving of this problem even when there are but a few number of lines given by position. I have likewise hit upon a Locus Planus since I saw you, $w^{\mathfrak{c}}$ I must own I like very well, it is this, $\mathrm{Si}$ in Semicirculo inscribatur quaevis Figura Aequilatera, et a puncto ducantur perpendiculares ad latera Figurae inscriptae, sitque summa quadratorum ex perpendicularibus aequalis spatio dato, Tanget punctum circumferentiam positione datam. I have not had time to write the Analysis and Composition of this L.ocus, yet, however, I know it will take up seven or eight pages of my write in Quarto, but if you are likewise desirous to see this Locus I shall endeavour to send you it. I have likewise met with a Porism, but as I have not yet fully considdered it I shall write you of this again

Roтн. Septr 27. 1743. 
To

Mr MatThew Stewart

at Rothesay in

Bute

\section{My Drar friend}

Glasgow 30. March 1744.

I got your letter of $23^{\mathrm{d}} \mathrm{Feb}^{\mathrm{r}}$ only the day before $I$ got Blairhall's. I caused James Robison give me notice of every boat going to Bute since $I$ got it, but not getting yet a distinct answer from Wm. Miller about his going to Mr Steuart, I delayed writing till now when I was eshamed to delay longer. I have wrote $\mathbf{M r}$ Stewart about his affair at length so need not repeat it. Daniel Monro came to me else perhaps I might have forgot to write in time by this boat. I am glad you are so near an end of your tryals to which I wish a prosperous issue. Mr Muir has sent in the schemes of the $1^{\text {st }}$. book six weeks ago, and has dunned Smith who cuts them by several letters without getting a return. Mr Muir thinks he is ashamed to write him without sending the figures along: and fancies that he is employed by the master of Elphinstoun in graving some Mapps of the shires of the Lothian's and that this has kept him from cutting the figures. had you been in Glasgow all this while, I believe the book would have been printed a quarter of year ago, (but you need not speak of this) pray send me the Enunciation only of the last of the Porisms in the $3^{d}$. book, tho I reckon that the difficultest part of the Invention. I shall defer the news concerning Mr Leechmans affair till we see what the Synod does in it, Mr Leechman having last Presbytery day craved leave under a Protest and publick Instrument to complain to the Synod of the injurious treatment he has received from the presbytery, and besides the boat is ready to go off. I am charmed with your Property of the circle, but have not got a minutes leasure to think of it or any mathematical subject this long time. I long much to see you in the mean time refresh me by letters upon every occasion of a boat or by post. My kind respects to your father. in haste $I$ am

\section{Dear Matthew}

Yours very affectionately

Rob: Simson

I had almost forgot to tell you that only on tuesday last $\mathrm{Mr}$ 
Foulis's books arrived at Lieth, I mean that part of them in which the Mathematici Veteres are.

So there is yet time enough to get my Lord Butes mind about it.

To

Mr Matthew Steunat

Professor of Mathematics in

the University of

Edinburgh

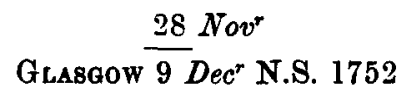

Dear Sir

The bearer of this John Coulter A.M. goes to Edinburgh to be Tutor to Sir Michael Steuarts sons, as he has read Mathematicks with me, and since by himself he is very desirous of the favour of your countenance and advice to both which I recommend him as $I$ know he is a modest young man and wants much to improve himself in every usefull studie and particularly Mathematicks.

I shall be very glad to hear from you, and if you will not give me any literary news, let me know at least how you and your family and friends are. I am

Dear Sir

Yours affectionately
ROB: Simson

[The following is a draft of a letter which was in all probability intended for Maclaurin.]

SiR,

When I reflect on the Many and Distinguished tokens of Friendship you was pleas'd to discover towards me, when I had the pleasure of attending your Lessons, I am greatly difficulted how to Apologize for my Conduct in not writting you long before now, to testify in some measure the grateful sense I retain of these 
undeserved Favours. Sometime after my return from your Lessons I was oblidg'd in order to gratify my Friends, to submit myself to undergo Trials in the Presbytery of Dunoon, and have only got them over a few weeks ago. As it is very likely from my present situation that I will be under a necessity of Preaching somewhat often, so I am afraid that I will find little or no time to employ in the Mathematical way.

I remember, Sir, while I attended your Lessons I had occasion to show you a small paper of mine, which with some other things contain'd this property of the Circle,

"Let there be any Regular Figure circumscrib'd about a Circle " and from any point in the Circumference of the Circle let there be " drawn perpendiculars to the sides of the Figure, twice the Sum of "the Squares of these perpendiculars will be equal to thrice the " multiple of the Square of the Semi-diameter of the Circle by the "number of the sides of the circumscrib'd Figure*."

As you was pleas'd to take greater notice of that Paper than I expected when I show'd it to you, and seem'd to be somewhat taken with this Property of the Circle, so this encourag'd me to considder these things more carefully afterwards, particularly the above mention'd Property of the Circle.

Sometime after I observ'd likewise this other Property of the Circle "That if there be any Regular Figure, but not a Triangle, " circumscrib'd about a Circle and from any point in the Circum"ference of the Circle there be drawn perpendiculars to the sides of "the Figure, twice the sum of the Cubes of these Perpendiculars "will be equal to fire times the multiple of the Cube of the Semi"diameter of the Circle by the number of the sides circumscrib'd "Figure f."

When I had discorered this Property of the Circle and compard it with the other Property before mention'd, I suspected these two Propertys might be only particular Cases of some more general Property of the Circle, with respect to the higher Powers of the Perpendiculars drawn from any point in the Circumference of the Circle to the sides of the circumscrib'd Figure. After I had

* See Matthew Stewart's Some General Theorems, pp. 20,21

$\dagger$ † " " " , " pp. 65,66 
considderd this for some time, I at last discover d this genera Property of the Circle.

" Let there be any Regular Figure circumscrib'd about a Circle, " and let $m$ be the Number of the sides of the Figure, and let $n$ be " any integer number less than $m$; if from any point in the Circum"ference of the Circle there be drawn Perpendiculars to the sides " of the circumscrib'd Figure, the sum of the $n$ Powers of these "Perpendiculars will be equal to the $n$ Power of the radius of the "Circle multiplied by *

$$
m \cdot \frac{1.3 .5 \cdot 7.9 . \text { \&c. } n \text { terms }}{1.23 \cdot 4 \cdot 5 . \text { \&c. } n \text { terms }},
$$

\section{I was resolv'd \&c [See below]}

From this General Property of the Circle I very soon observ'd that another Property as General and Elegant as this naturally flow'd namely, "Iet there be any Regular Figure inscrib'd in a " Circle, and let $m$ be the number of the sides of the inscrib'd "Figure, and let $n$ be any integer number less than $m$, If from all " the angles of the inscrib'd Figure there be drawn right Lines to "any point in the Circumference of the Circle, the Sum of the " $2 n$ Powers of these lines will be equal to the $2 n$ Power of the " radius of the Circle multiplied by $\dagger$

$$
m .2^{n} \cdot \frac{1 . \ddot{3} \cdot 5.7 .9 . \& c . n \text { terms }}{1.2 .3 .4 .5 . \& c . n \text { terms }} "
$$

This Property of the Circle is but one case of another more general which is this, "I Let there be any Regular Figure inscrib'd " in a Circle and let $m$ be the number of the sides of the inscrib'd "Figure and let $n$ be any integer Number less than $m$, and from " all the angles of the inscrib'd Figure let there be drawn right "lines to a point in the plane of the Circle and let the Sum of " the $2 n$ Powers of these lines be invariable, the point in the plain " of the Circle will be in the Circumference of another Circle

\begin{tabular}{|c|c|c|c|c|c|c|}
\hline$\dagger$, & ", & ,. & " & " & ", & pp. $109-110$ \\
\hline$\ddagger$ & ", & , & ," & ", & $"$ & p. 112 \\
\hline
\end{tabular}
" concentric with the former. 
From this last Property naturally flows this other Property . . .

I was resolvd to have added some more Propertys of the Circle, but as this letter is of a greater length than $I$ at first expected, I shall reserve these till I have occasion to write you again. I persuade myself from what I have already experienc'd of your goodness, that you will favour me with a return as soon as you conveniently can. And as this comes to you by my friend Mr Sands Bookseller in the Parliament closs you may commit your Letter for me to his care.

Please let me know how your Philosophical Society is like to go on, and how soon they propose to publish. We have been somewhat alarm'd here to hear that Mercury has been amissing for some time, but as this has not been taken notice of in any of the Publick Papers we saw here we do not know if we are to credit this report, I should be very fond to know the truth of this from you.

This is from D. S. with the greatest

Sincereity, Your most humble and obed Servt

RoTH. 20 May 1744.

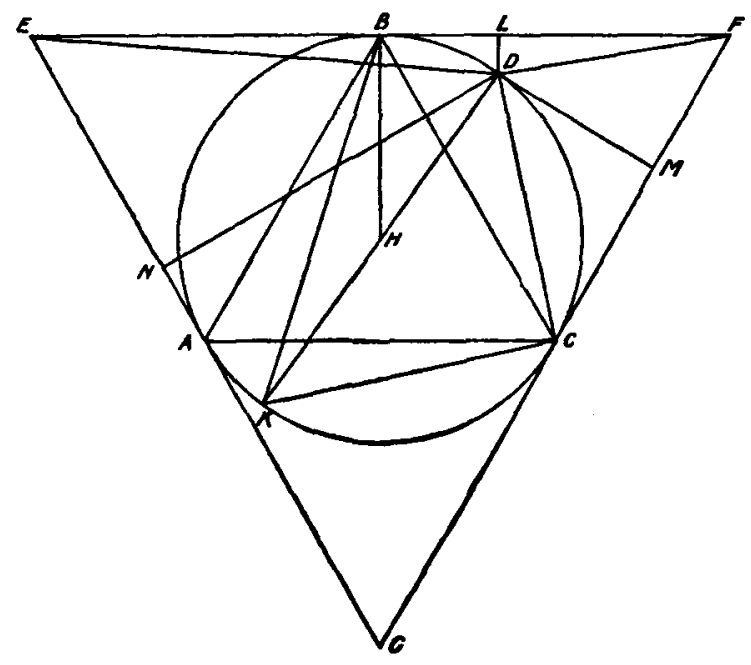




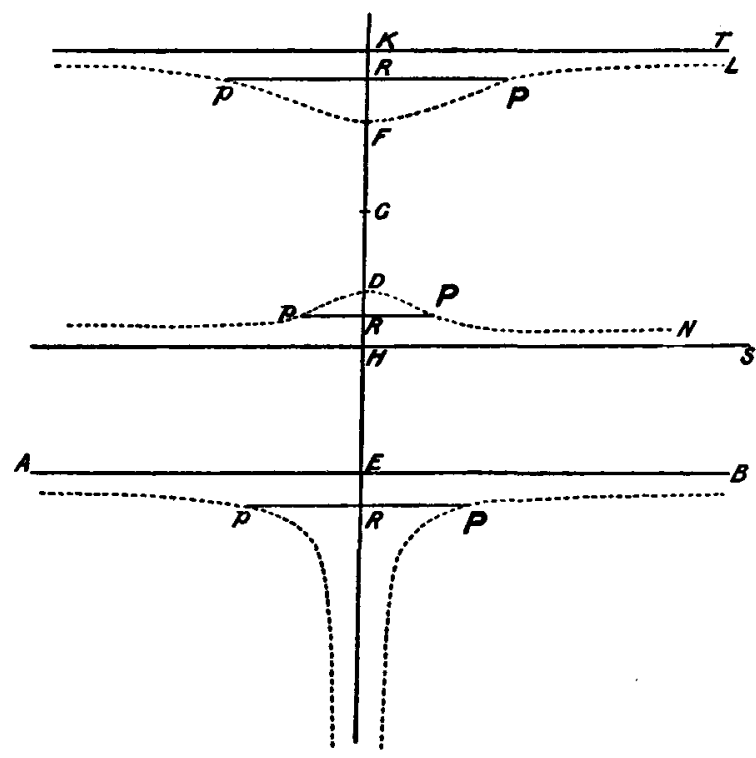

To

Mr Matrief Stewart Professor of Mathema-

ticks in the University of

Edenburgh

Sir

The figure of which you gave me the construction, is drawn in a rude manner on the margin here. The lines are marked with the same letters as you did, so that you will understand the scheme without more words.

The figure has three Asymptotes, all parallel ; and a fourth one KE cutting them at right angles. It consists of two conchoidal figures, and two hyperbolical ones. Any line such as $p R P$, parallel to the three Asymptotes, and cutting the curve in two points $p \& P$, is bisected by the fourth Asymptote KE. So that the areas, in each figure, on different sides of the line $\mathrm{KE}$ are equal to one another.

Now I desire you will let me know what area you want, without asking one jot more or less than what is sufficient for your purpose. For when a curve is not quadrable, the whole area or different parts of it, are to be found by different artifices. The sum of two 
areas is to be found by one rule, and their difference by another. And sometimes the sum or difference may be found, when the areas themselves cannot. Sometimes the whole area of a figure may be found with ease, when the parts of it cannot be assigned generally without great difficulty. For this reason I want to know your demand with all the limitations, it will admit of. Or if you will send me your probleme I shal be best able to judge of the limitations myself. As this is our post day, and I have several letters to write, I hope you will excuse this confused scrol, but I hope you will understand it.

LeadHILLS 22 May 1755

Sir

Your most obedient

humble Servant

JAMES StiRling 